\title{
Family Firms and Productivity: The Role of Institutional Quality
}

\author{
Lidia Mannarino $^{1}$, Valeria Pupo ${ }^{1} \&$ Fernanda Ricotta $^{1}$ \\ ${ }^{1}$ Department of Economics, Statistics and Finance, University of Calabria, Italy \\ Correspondence: Lidia Mannarino, Department of Economics, Statistics and Finance, University of Calabria, \\ Rende (CS), Italy. Tel: 39-098-449-2405. E-mail: lidia.mannarino@unical.it
}

Received: June 30, 2016

Accepted: August 6, $2016 \quad$ Online Published: September 20, 2016

doi:10.5539/ijbm.v11n10p343

URL: http://dx.doi.org/10.5539/ijbm.v11n10p343

\begin{abstract}
The main aim of this research is to investigate the influence the institutional environment has on the difference in performance between Italian family firms run by a family member and firms run by a professional manager. By using total factor productivity (TFP) as a measure of performance, we find that family-run firms are less productive than firms run by outside managers when institutional quality is high, but that the results are less obvious when institutional quality is low. The difference in performance is not significant, but by using the level of corruption as a measure of institutional quality, older family firms are found to be more productive than firms run by outside managers.
\end{abstract}

Keywords: Family firms, TFP, institutions

\section{Introduction}

Although a vast quantity of literature has investigated the impact of family influence on firms' performance (for a survey see Carney, van Essen, Gedajlovic, \& Heugens, 2015; Chrisman, Kellermanns, Chan, \& Liano, 2010; Schulze \& Gedajlovich, 2010 amongst others), the empirical evidence is mixed (Rutherford, Kuratko, \& Holt, 2008) and the relationship between family involvement and performance remains controversial. Some studies show that family firms out-perform non-family firms (Anderson \& Reeb, 2003; Andres, 2008; Lee, 2006; McConaughy, Matthews, \& Fialko, 2001; Sraer \& Thesmar, 2007), whereas others find the opposite (Block, Jaskiewicz, \& Miller, 2011; Cucculelli \& Micucci, 2008; Villalonga \& Amit, 2006). A number of studies also demonstrate that the relationship between family involvement and firm performance is complex, nonlinear and multifaceted (Barth, Gulbrandsen, \& Schøne, 2005; Cucculelli, Mannarino, Pupo, \& Ricotta, 2014; Miller, Breton-Miller, Lester, \& Cannella, 2007), so suggesting the influence of moderating factors.

This literature does not, however, take into account the influence of context on family firm behaviour, although many authors have considered the influence of the institutional environment on firms' productivity (among others, Acemoglu \& Robinson, 2008; Chanda \& Dalgaard, 2008; Lasagni, Nifo, \& Vecchione, 2015; McGuinness, 2007).

Generally, these studies provide evidence of significant correlations between institutional quality and economic performance, showing how good institutions can create a favourable business environment which facilitates investments, promotes accumulation of physical and human capital (Rodrik, Subramanian, \& Trebbi, 2004) and encourages firms to invest in knowledge creation and transfer (Loayza, Oviedo, \& Serven, 2005).

Besides the potential impact of institutional environment on firm performance, scholars are now beginning to recognise that family firms are also affected by context (Carney et al., 2015; Gedajlovic, Carney, Chrisman, \& Kellermanns, 2012; Liu, Yang, \& Zhang, 2012; Lumpkin, Steier, \& Wright, 2011; Wright, Chrisman, Chua, \& Steier, 2014) and it is surprising to see how the little research that has looked into the issue focuses particularly on family firms in transition economies (Aguilera \& Crespi-Cladera, 2012; Amit, Ding, Villalonga, \& Zhang, 2015; Banalieva, Eddleston, \& Zellweger, 2015; Miller, Lee, Chang, \& Le Breton-Miller, 2009; Peng \& Jiang, 2010). This research considers the case of a developed economy, Italy, with the aim of investigating the influence of the institutional environment on the difference in performance between firms run by families and firms run by outside managers.

Italy is an interesting research subject for our aim since it combines heterogeneity in institutional development across its provinces and homogeneity in cultural norms, with a great emphasis on family values. Indeed, Italy has been a politically and legally unified country since 1861 and, therefore, the territories have common policies, 
institutions, laws, judiciary and education systems and, overall, the country is ethnically and religiously homogeneous. In spite of this apparent institutional homogeneity, differences exist in local government efficiency between the North and the South of the country. This peculiarity has inspired many scholars to look at the links between institutional quality and economic results, from the work of Putnam (1993) to many more recent contributions (among others, Charron, Djkstra, \& Lapuente, 2014; Di Liberto \& Sideri, 2015; Lasagni et al., 2015).

Defining institutions is notoriously difficult and the current literature on the topic does not agree on a common definition. However, detailed analysis of these issues goes beyond the scope of this research. Here, we just stress that the indicator used to measure institutional quality should consider several dimensions in order to capture the differences in formal and informal institutions across regions. Moreover, the use of a synthetic index offers the advantage that it is less likely to be influenced by specific local factors which are not necessarily related to the quality of the institutional environment. Following this approach, we consider the "Institutional Quality Index (IQI)" indicator recently proposed by Nifo and Vecchione (2014) as a proxy for institutional environment. This is a composite indicator of the quality of institutions at the province level in Italy and is comprised of information on major dimensions of institutional quality (social participation, governance, regulation, law enforcement and corruption).

In order to investigate the influence of institutional quality on firm performance, we consider the management and not ownership because, as many have suggested (Barth et al., 2005; Bloom \& Van Reenen, 2007; Bloom, Sadun, \& Van Reenen, 2008; Hart, 2001; Sciascia \& Mazzola, 2008), management may affect a firm's economic performance more than the mode of ownership per se.

The empirical evidence is based on data from the Xth UniCredit-Capitalia survey (2008) of Italian manufacturing firms, compiled on the basis of the information collected in a questionnaire and complemented with balance sheet data. We use Total factor productivity (TFP), estimated at firm level by using the Levinshon and Petrin (2003) approach, as a measure of performance in order to take account of simultaneity problems. We use TFP because it can be considered a realistic measure of firm performance for several reasons. First, unlike financial measurements (ROE, ROI, Tobin's Q), productivity is less exposed to manipulation by accountants (Palia \& Lichtenberg, 1999). Second, TFP intrinsically determines the equilibrium value of financial variables, such as profit and stock price (Griffell-Tatje \& Lovell, 1999). In addition, performance measures based on market prices can only be used if the stock market is efficient (Brealey \& Myers, 2000), which is not the case for Italy. Moreover, the use of market price based measures enables researchers only to consider listed firms, which are just a small percentage of firms, while our sample combines both listed and no listed firms. Finally, many contributions have shown how the decline in Italian productivity of the last 20 years can be attributed to low TFP growth (amongst others, Accetturo et al., 2013; Aiello, Pupo, \& Ricotta, 2009; Bassanetti, Iommi, Jona-Lasinio, \& Zollino, 2004; Daveri \& Jonia-Lasinio, 2005; OECD, 2007; Van Ark, O’Mahony, \& Ypma, 2007). Therefore, studies which aim to analyse the factors that influence TFP are central to understanding what should be done to strengthen the Italian productive system.

The main contribution of this study is its empirical assessment of the role institutions have in influencing the relationship between family management and firm performance, an area where the majority of empirical research is largely silent (van Essen, Carney, Gedajlovic, \& Heugens, 2015). To the best of our knowledge, no published paper has explored this issue in terms of the Italian market and the empirical evidence on this subject in international literature is extremely limited. Moreover, with the exception of Amit et al. (2015), previous studies have not considered the different dimensions of institutional quality but, instead, have focused on specific aspects of institutional quality, such as quality of the rule of law (Carney \& Gedajlovic, 2002; Gilson, 2007; La Porta, Lopez De Silanes, \& Shleifer, 1999), formal legal regimes and shareholder protection rules (amongst others Stevens, Kidwell, \& Sprague, 2015; van Essen et al., 2015).

The findings demonstrate that firms run by a professional manager exhibit a superior performance to family managed firms when the institutional quality is high, while the gap in performance disappears when the institutional quality is low. However, by considering the single aspects of institutional quality, we find that, older family firms are more productive than firms run by outside managers in contexts with a marked presence of corruption.

The work is organised as follows. In the following section, we present a review of the theoretical issues and empirical evidence. We then describe the sample and the empirical model. In the subsequent section, we present the results. The final section concludes. 


\section{Literature Review}

In today's global economic system, family firms are generally acknowledged as the prevailing actors in both industrialised and developing countries (La Porta et al., 1999; Faccio \& Lang, 2002). Consequently, the performance of family firms has received great attention in the literature on business strategy and financial economics.

A number of studies have investigated the impact family influence has on a firm's performance, but, from both theoretical and empirical perspectives, there is ambiguity surrounding this relationship. In attempts to understand this rapport, scholars have drawn on a range of theories such as agency theory (Schulze, Lubatkin, Dino, \& Buchholtz, 2001; Schulze, Lubatkin, \& Dino, 2003), stewardship theory (Miller, Breton-Miller, \& Scholnick, 2008) and the resource-based view of the firm (Habbershon \& Williams, 1999; Sirmon \& Hitt, 2003) and each has revealed evidence of both benefits and costs of family involvement.

Indeed, empirical results to date have been mixed and conflicting, and a review of past research into the family business-firm performance link reveals heterogeneous findings, with authors reporting positive, negative and neutral relationships (Carney et al., 2015; Garcia-Castro \& Aguilera, 2014; Mazzi, 2011; O'Boyle, Pollack, \& Rutherford, 2012; Rutherford et al., 2008; Wagner, Block, Miller, Schwens, \& Xi, 2015)

The lack of homogeneity in the results of these studies suggests that the relationships between family businesses and corporate performance are complex and very probably mediated by factors that have not been included in these analyses and that many of the causal antecedents, underlying mechanisms, and key implications of family governance and ownership still remain ambiguous (Gedajlovich et al., 2012). Previous research has predominantly used agency theory and the resource-based view (RBV) as the main explanations of family business-performance relationships, focusing on internal dynamics and resources without considering that the utility of any resource will vary as a consequence of the environmental opportunity to which it is applied (Barney, 1991).

Indeed, a growing body of literature suggests that the performance of family businesses is affected by the external environment in terms of such factors as economic development, national cultures and the quality of the institutional environment, particularly regarding the legal environment and the quality of the rule of law (Carney \& Gedajlovic, 2002; Gedajlovic et al., 2012; Gilson, 2007; La Porta et al., 1999).

As a consequence, research on family businesses would be enriched by a better understanding of the external conditions that may affect the performance and development of family firms. The relationship between national institutions, strategy, and performance is a rapidly growing area of research that fits into the genre of literature known as institution-based view (Carney, Gedajlovic, Heugens, van Essen, \& Van Oosterhout, 2011; Liu et al., 2012; Peng \& Jiang, 2010; van Essen, Heugens, Otten, \& Van Oosterhout, 2012). A basic forecast of this literature is that family firms will be prevalent in less developed economic regions (Chang, Chrisman, Chua, \& Kellermanns, 2008) because they enjoy competitive advantages when there are underdeveloped legal frameworks and inefficient public administration (Gedajlovic et al., 2012).

Contending theories suggest that the quality of the institutional environment can either positively or negatively moderate the performance of family firms (Carney et al., 2015; Gedajlovic et al., 2012; Liu et al., 2012).

For example, family firms enjoy advantages in regimes with weak commercial law due to their capacity for leveraging their reputations for being trustworthy, since relational contracting may function as an alternative contract enforcement mechanism (Gilson, 2007). More generally, family firms, with competitive advantages in the areas of social capital (Sirmon \& Hitt, 2003) and relational contracting (Gómez-Mejía, Nunez-Nickel, \& Gutierrez, 2001), can outperform non-family firms because these assets help firms fill institutional voids (Miller et al., 2009).

However, the literature on the costs and benefits of family firms' advantages in institutionally less developed environments is divided. Some authors hold that relational contracting is beneficial, indicating a capacity for filling institutional voids (Miller et al., 2009), while others believe that relational contracting is associated with cronyism (James, 2008) and rent-seeking (Morck \& Yeung, 2004), so acting as a hindrance to the development of the territory where these firms operate.

As regards the latter, research suggests that a family firm may have a special relationship with political power. Family-owned companies are ideal partners of political power because they are companies in which control is stable. It is preferable in the eyes of politicians to grant aid to companies which have long term horizons and whose owners tend to remain in charge for a long time rather than make agreements with companies which have a high turnover of control. Stable companies can then return the favour. These connections with politicians may 
result in aid and subsidies, privileged access to credit, contracts to supply the public administration and favourable rules and regulations (Morck, Stangeland, \& Yeung, 2000; Faccio, 2006). Moreover, this relationship with political power makes family firms tend to lack innovative propensity since they are more likely to maximise their profits by investing in political rent-seeking behaviour than in innovation (Ellington, Jones, \& Deane, 1996; Morck \& Yeung, 2004).

In terms of the arguments outlined, family firms are ill-equipped because family members are overly concerned with wealth preservation and, thus, limit their investments (Carney, 2005). However, when the degree of technological dynamism in the economy is high, the prominence of relationships in business life weakens, the social connections built by the family in the past are more likely to become obsolete and their transfer across generations is less productive.

This paper strives to contribute insight to this issue by testing whether the effect of family-management versus outside management on a firm's productivity varies across different institutional contexts and in what direction. In particular, we expect that family management is good for firm performance in contexts where institutions are weak, but bad for firm performance in contexts with strong institutions.

\section{Data and Method}

\subsection{Data Description}

Microdata used in this paper come from the Xth UniCredit-Capitalia survey (2008), which was compiled on the basis of the information collected by means of a questionnaire sent to a sample of Italian manufacturing firms.

The questionnaire refers to 2004-2006 and includes information on firm structure, ownership, work force, investments in physical and technological capital, as well as the degree of internationalisation. The survey is integrated with balance sheet data drawn from the Aida database managed by Bureau van Dijk and retrieves nine years of balance sheet information for each surveyed firm, from 1998 to 2006.

The survey, which covers a sample of firms with 11 to 500 employees and all firms with over 500 employees, is the most complete source of information on the Italian manufacturing system, in particular regarding medium and large firms. Although the original data-set comprises 5,100 firms, we use a sample of 2,428 firms which is obtained after carrying out a data cleaning procedure (Note 1).

As a proxy for institutional quality, we consider the "Institutional Quality Index (IQI)" indicator recently proposed by Nifo and Vecchione (2014) with reference to Italian provinces. The construction of the indicator mimics the World Governance Indicator proposed by Kaufmann, Kraay, and Mastruzzi (2010). It is based on 24 elementary indexes aggregated into five groups regarding certain major dimensions of a governance system: Voice and accountability, Government effectiveness, Regulatory quality, Rule of law and Corruption (Note 2). The use of an indicator as IQI has various advantages. First of all, as it is a synthetic index, it considers different dimensions of institutional quality. Secondly, it is less likely to be in influenced by specific local factors that do not necessarily relate to the quality of the institutional environment. For example, observed regional differences in a single indicator such as the books published or social cooperatives indicators (included in the elementary index, "Voice and accountability") may be influenced by specific local demographic characteristics.

The dependent variable, the TFP, estimated by using Levinshon and Petrin's (2003) approach, was calculated in Aiello, Pupo, and Ricotta (2012), to which reference is made for details.

Table 1 presents some descriptive statistics of the sample of firms used in the empirical analysis and reports the distribution of firms on the basis of the institutional environment in which firms are located (low and high institutional quality) and management regime (owner management and professional management).

As regards institutional quality, we consider provinces (Note 3) to have high (low) institutional quality when they show a value of IQI above (below) the median index value (Note 4). With respect to the distribution of firms by management type, information is drawn from responses to a question included in the Xth Capitalia-UniCredit questionnaire (2008). We distinguish two types of firms: (i) family firms run by a family member (owner management); (ii) firms run by a professional manager, which includes both family firms run by a manager from outside the family and non-family firms, presumably also run by a professional manager (professional management).

Firm distribution by quality of institutions reveals a predominance of enterprises located in environments of high institutional quality: $80 \%$ of the sample $(1,965$ out of 2,428$)$, while only $20 \%$ of firms were based in provinces of low institutional quality (463 out of 2,428).

Family management is the dominant form of management: firms run by a family member make up $57 \%$ of the 
sample in both low and of high quality institutional environments.

As far as sector, size and age are concerned, we do not find relevant differences in the distribution of firms according to low and high institutional quality: firms operate predominantly in traditional sectors ( $49 \%$ of the total), are mainly small and medium firms ( $58 \%$ and $35 \%$, respectively), and adult firms ( $57 \%$ of the total).

Conversely, the territorial distribution shows a clear institutional quality divide between the North and the South of the country. Indeed, when considering the whole sample, firm distribution by area reveals a concentration of enterprises in the North of Italy ( $75 \%$ of the total, while $9 \%$ were based in the South and $16 \%$ in the Centre), but the percentage is reduced to just $32 \%$ in low quality institutional environments $(50 \%$ in the South and $18 \%$ in the Centre), while it increases to $85 \%$ when considering high quality institutional environments (none in the South and $15 \%$ in the Centre). Regarding the variables used in the empirical analysis, what clearly emerges from table 1 is that the TFP in institutional environments of low quality and in firms run by a family member is lower both overall and for all the sub-samples of firms considered: by sector, size, territorial area and age.

Table 1. Descriptive statistics

\begin{tabular}{|c|c|c|c|c|c|c|c|c|c|}
\hline & \multicolumn{3}{|c|}{ Low Institutional Quality } & \multicolumn{3}{|c|}{ High Institutional Quality } & \multicolumn{3}{|c|}{$\%$ of firms } \\
\hline & All & $\begin{array}{c}\text { Owner } \\
\text { management }\end{array}$ & $\begin{array}{l}\text { Professional } \\
\text { management }\end{array}$ & All & $\begin{array}{c}\text { Owner } \\
\text { management }\end{array}$ & $\begin{array}{l}\text { Professional } \\
\text { management }\end{array}$ & All & Low & High \\
\hline TFP & 769 & 702 & 861 & 885 & 839 & 948 & & & \\
\hline \multicolumn{10}{|l|}{ By Sector } \\
\hline Supplier dominated & 691 & 645 & 765 & 813 & 789 & 847 & $49 \%$ & $61 \%$ & $46 \%$ \\
\hline Scale intensive & 840 & 835 & 845 & 947 & 836 & 1123 & $18 \%$ & $18 \%$ & $19 \%$ \\
\hline Specialised suppliers & 916 & 767 & 1.084 & 939 & 912 & 969 & $28 \%$ & $19 \%$ & $31 \%$ \\
\hline Science based & 1051 & 905 & 1393 & 1000 & 921 & 1082 & $4 \%$ & $2 \%$ & $4 \%$ \\
\hline \multicolumn{10}{|l|}{ By Size } \\
\hline Small (11-50) & 623 & 594 & 672 & 750 & 729 & 780,55 & $58 \%$ & $54 \%$ & $58 \%$ \\
\hline Medium (50-250) & 867 & 812 & 928 & 987 & 961 & 1021 & $35 \%$ & $38 \%$ & $34 \%$ \\
\hline Large $(>250)$ & 1356 & 1188 & 1480 & 1513 & 1364 & 1613 & $7 \%$ & $7 \%$ & $7 \%$ \\
\hline \multicolumn{10}{|l|}{ By Territorial area } \\
\hline North & 808 & 691 & 947 & 889 & 837 & 960 & $75 \%$ & $32 \%$ & $85 \%$ \\
\hline Center & 762 & 773 & 744 & 865 & 852 & 883 & $16 \%$ & $18 \%$ & $15 \%$ \\
\hline South & 746 & 681 & 838 & - & - & - & $9 \%$ & $50 \%$ & $0,0 \%$ \\
\hline \multicolumn{10}{|l|}{ By Age } \\
\hline Young $(<20)$ & 666 & 629 & 729 & 872 & 794 & 949 & $31 \%$ & $39 \%$ & $29 \%$ \\
\hline Adult (20-40) & 804 & 710 & 913 & 860 & 832 & 906 & $57 \%$ & $55 \%$ & $57 \%$ \\
\hline Mature $(>40)$ & 1072 & 1063 & 1086 & 1023 & 962 & 1098 & $12 \%$ & $6 \%$ & $14 \%$ \\
\hline N. observations & 463 & 264 & 199 & 1965 & 1125 & 840 & 2428 & 463 & 1965 \\
\hline
\end{tabular}

Note. All variables are computed for 2006. Data in value are deflated and expressed in Euros. Shares of firms are computed with respect to the total of the column.

Source: elaborations on data UniCredit-Capitalia (2008).

\subsection{Empirical Model and Estimation Methodology}

In order to examine whether the institutional environment affects firm performance and, especially, whether the quality of institutions influence the difference in performance between family-managed firms and non-family managed firms, we estimate a TFP equation of the form:

$$
\omega=\beta_{0}+\beta_{1} D_{F M}+\sum_{j=1}^{k} \gamma_{j} X_{j}+\sum_{s=1}^{v} \eta_{s} D_{s}+\varphi I Q I+\varepsilon
$$

Where $\omega$ is firm TFP (in logarithm) estimated by using Levinsohn and Petrin's approach, $D_{F M}$ is a binary variable which takes a value one if the firm is run by a member of the owner family and zero otherwise, $\mathrm{X}$ a vector of firm-level variables that were highlighted by previous literature as being important drivers of TFP, and $\mathrm{D}$ is a set of sector dummies, which group firms according to the Pavitt taxonomy, and territorial area dummies. Parameter measures whether firms managed by a member of the owner family are more or less productive than 
non-family-managed firms. Firm characteristics include: firm size (measured by the log of employment); the firm age log; a dummy variable equal to one if the firm is listed on the stock market; a proxy for human capital (the share of white collar workers out of total number of employees); capital intensity at firm level (proxied by the assets-per-employee ratio) and the ownership concentration (measured as the share of capital of the major shareholder). An interaction variable between family management and age is considered in set X of firm-level characteristics in order to test whether older family managed firms show different efficiency levels compared with non-family managed firms (Cucculelli et al., 2014). IQI represents the Institutional Quality Indicator at provincial level as calculated by Nifo and Vecchione (2014).

This indicator is considered in specification (1), but is also used to distinguish between firms located in provinces with high/low institutional quality. These two subsamples allow us to test to what extent family managed firms perform differently from non-family managed firms in different institutional environments. To be more precise, we estimate equation (1) by considering the sample of firms located in provinces with low institutional efficiency separately from the sample of firms operating in provinces with high institutional quality. Equation (1) is estimated using standard ordinary least squares by considering average values of 2004-2006 period for TFP and employment (Note 5). Capital intensity refers to 2005 while all other firm-level variables refer to 2006. For the IQI, the 2004 value is considered.

As regards the estimation method, the assumption that the errors are independent might be violated since firms from the same province are likely to be more similar to each other than to firms from different provinces (because of socio-economic factors for example). For this reason, we control for the potential downward bias in the estimated errors by clustering firms at provincial level. The regression with the cluster option relaxes the assumption of independence and, therefore, compared with the Ordinary Least Squares (OLS) without clustering, increases the error term to accommodate the lack of independence of firms within each province.

\section{Results}

\subsection{Effects of Family Management on TFP in Different Institutional Contexts}

Results are displayed in tables 2. Equation [1] is estimated on the entire sample in columns (1) to (3), while on the subsamples of provinces with low and high institutional environment in the final two columns. Column (1) reports the results of the base model.

The initial evidence regards the impact exerted by firms' characteristics as explanatory factors of TFP, which are not substantially different from those obtained by other researchers (Note 6). In particular, we confirm that capital intensity and equity concentration are positively correlated with TFP (Barth et al., 2005; Cucculelli \& Marchionne 2012) and that human capital leads to higher firm TFP since it directly affects the possibility to introduce and use more productive processes (Cohen \& Levinthal 1990; Ascari \& Di Cosmo, 2005). Moreover, the positive coefficient associated with employment highlights the role of size in TFP indicating that economies of scale are at work. In line with the literature, listed firms display higher productivity (see, e.g., Barth et al., 2005), while firms in the supplier dominated sector (the reference group in the model) have, ceteris paribus, a lower TFP. Finally, firms located in southern Italy exhibit lower productivity, as has already been stressed in the literature (Aiello, Pupo, \& Ricotta F., 2014; Ascari and Di Cosmo, 2005; Byrne, Fazio, \& Piacentino, 2009), while firms operating in the Centre of Italy do not seem to differ from northern firms (the reference group).

Table 2. Family management and institutional quality

\begin{tabular}{|c|c|c|c|c|c|c|}
\hline & (1) & $\begin{array}{l}\text { Family Firms } \\
\text { Second stage }\end{array}$ & First stage & (3) & $\begin{array}{l}\text { Low } \\
\text { (4) }\end{array}$ & $\begin{array}{l}\text { High } \\
(5)\end{array}$ \\
\hline Constant & $\begin{array}{l}6.6307 * * * \\
(0.013)\end{array}$ & $\begin{array}{l}5.4917^{* * *} \\
(0.262)\end{array}$ & $\begin{array}{l}1.7651^{* * *} \\
(0.346)\end{array}$ & $\begin{array}{l}6.4285^{* * *} \\
(0.068)\end{array}$ & $\begin{array}{l}6.5382 * * * \\
(0.025)\end{array}$ & $\begin{array}{l}6.6565^{* * *} \\
(0.013)\end{array}$ \\
\hline IQI & & & & $\begin{array}{l}0.2764 * * * \\
(0.094)\end{array}$ & & \\
\hline Family Management & $\begin{array}{l}-0.0424 * * \\
(0.017)\end{array}$ & $\begin{array}{l}-0.2762 \\
(0.244)\end{array}$ & & $\begin{array}{l}-0.0423 * * \\
(0.017)\end{array}$ & $\begin{array}{l}-0.0305 \\
(0.035)\end{array}$ & $\begin{array}{l}-0.0375^{*} \\
(0.019)\end{array}$ \\
\hline Capital Intensity & $\begin{array}{l}0.0621 * * * \\
(0.011)\end{array}$ & $\begin{array}{l}0.0524^{* * *} \\
(0.008)\end{array}$ & $\begin{array}{l}-0.0075 \\
(0.033)\end{array}$ & $\begin{array}{l}0.0632 * * * \\
(0.010)\end{array}$ & $\begin{array}{l}0.1053^{* * *} \\
(0.016)\end{array}$ & $\begin{array}{l}0.0548^{* * *} \\
(0.011)\end{array}$ \\
\hline Age $(\log )$ & $\begin{array}{l}0.0130 \\
(0.011)\end{array}$ & $\begin{array}{l}0.0422 * * \\
(0.017)\end{array}$ & $\begin{array}{l}0.1254 * \\
(0.070)\end{array}$ & $\begin{array}{l}0.0099 \\
(0.011)\end{array}$ & $\begin{array}{l}0.0456^{*} \\
(0.027)\end{array}$ & $\begin{array}{l}0.0033 \\
(0.011)\end{array}$ \\
\hline
\end{tabular}




\begin{tabular}{|c|c|c|c|c|c|c|}
\hline \multirow[t]{2}{*}{ Family Management *Age } & $0.0661^{* *}$ & & & $0.0634^{* *}$ & 0.0618 & 0.0556 \\
\hline & $(0.031)$ & & & $(0.030)$ & $(0.061)$ & $(0.035)$ \\
\hline \multirow[t]{2}{*}{ Size (log of employees) } & $0.2056^{* * *}$ & $0.1919 * * *$ & $-0.1902 * * *$ & $0.2076^{* * *}$ & $0.2310^{* * *}$ & $0.2027 * * *$ \\
\hline & $(0.008)$ & $(0.014)$ & $(0.044)$ & $(0.008)$ & $(0.022)$ & $(0.008)$ \\
\hline \multirow[t]{2}{*}{ Equity concentration } & $0.0012 * * *$ & 0.0005 & $-0.0048 * * *$ & $0.0011 * * *$ & 0.0002 & $0.0014 * * *$ \\
\hline & $(0.000)$ & $(0.000)$ & $(0.001)$ & $(0.000)$ & $(0.001)$ & $(0.000)$ \\
\hline \multirow[t]{2}{*}{ Listed firm } & $0.1653^{* * *}$ & -0.0307 & $-1.1191 * * *$ & $0.1672 * * *$ & $0.3411 * *$ & $0.1271 * * *$ \\
\hline & $(0.047)$ & $(0.146)$ & $(0.424)$ & $(0.048)$ & $(0.156)$ & $(0.047)$ \\
\hline \multirow[t]{2}{*}{ Human capital } & $0.2694 * * *$ & $0.2991^{* * *}$ & $0.3895^{*}$ & $0.2642 * * *$ & $0.3012 * * *$ & $0.2501 * * *$ \\
\hline & $(0.029)$ & $(0.041)$ & $(0.201)$ & $(0.028)$ & $(0.078)$ & $(0.031)$ \\
\hline \multirow[t]{2}{*}{ South } & $-0.1419 * * *$ & $-0.1582 * * *$ & 0.0655 & -0.0441 & -0.0476 & \\
\hline & $(0.023)$ & $(0.033)$ & $(0.160)$ & $(0.039)$ & $(0.040)$ & \\
\hline \multirow[t]{2}{*}{ Center } & -0.0346 & -0.0326 & -0.1390 & -0.0347 & -0.0018 & -0.0228 \\
\hline & $(0.029)$ & $(0.026)$ & $(0.116)$ & $(0.025)$ & $(0.051)$ & $(0.032)$ \\
\hline \multirow[t]{2}{*}{ Pavitt 2} & $0.1376^{* * *}$ & $0.1056^{* * *}$ & -0.0981 & $0.1326 * * *$ & $0.2087 * * *$ & $0.1127 * * *$ \\
\hline & $(0.021)$ & $(0.026)$ & $(0.120)$ & $(0.020)$ & $(0.045)$ & $(0.023)$ \\
\hline \multirow[t]{2}{*}{ Pavitt 3} & $0.1417 * * *$ & $0.1395 * * *$ & $-0.2443 * *$ & $0.1373 * * *$ & $0.1854 * * *$ & $0.1271 * * *$ \\
\hline & $(0.017)$ & $(0.025)$ & $(0.104)$ & $(0.017)$ & $(0.057)$ & $(0.018)$ \\
\hline \multirow[t]{2}{*}{ Pavitt 4} & $0.1921^{* * *}$ & $0.1602 * * *$ & -0.1466 & $0.1813^{* * *}$ & $0.2228 * *$ & $0.1797 * * *$ \\
\hline & $(0.035)$ & $(0.051)$ & $(0.242)$ & $(0.033)$ & $(0.104)$ & $(0.039)$ \\
\hline \multirow[t]{2}{*}{ Agreement to vote } & & & $0.2268^{* *}$ & & & \\
\hline & & & $(0.089)$ & & & \\
\hline \multirow[t]{2}{*}{ Lambda } & & 0.1327 & & & & \\
\hline & & $(0.128)$ & & & & \\
\hline Wald $\chi^{2}$ & & 699.35 & & & & \\
\hline R-squared & 0.337 & & & 0.341 & 0.404 & 0.321 \\
\hline Observations & 2,428 & 1,555 & 1,555 & 2,428 & 463 & 1,965 \\
\hline
\end{tabular}

Robust standard errors in parentheses. Level of significance: *** $1 \% ; * * 5 \% ; * 10 \%$.

In model (1), we test whether family managed firms perform differently from non-family managed firms. We found that family managed firms are, on average, $4.2 \%$ less productive than non-family firms. This result is in line with Cucculelli and Marchionne (2012) for Italy and Barth et al. (2005) for Norway. On the other hand, even though not strictly comparable with our results, other papers focusing on EU firms find that family-controlled companies perform better than non-family firms (Barontino \& Caprio, 2006; Maury, 2006; Pindado, Requejo, \& Torre, 2008) (Note 7), and the same is found for Spain (Arosa, Iturralde, \& Maseda, 2010) and France (Sraer \& Thesmar, 2007) individually (Note 8).

When it comes to the learning process, the estimated result in Table 2 (model 1) shows that age plays a crucial role in explaining the relative efficiency of family firms. The coefficient of the interaction effect between age and $D_{F M}$ is positive and significant, so showing, as in Cucculelli et al. (2014), that the negative effect of family management on TFP vanishes with age because family-managed firms become more efficient as they mature. Over time firms specialise and discover ways to standardise, coordinate and speed up their production processes, as well as methods to reduce costs and improve quality.

However, if for family firms the decision to run the firm or to hire an outside manager is correlated with unobservables that affect TFP, our result about the difference in performance between family and outside managers could potentially suffer from the problem of endogeneity and standard regression techniques could lead to biased and inconsistent estimators. In order to take this into account for the sample of family owned firms, we apply the treatment effect model that allows us to consider the effect of an endogenously choice binary treatment on another endogenous continuous variable, conditioned on two sets of independent variables (Greene, 2000) (Note 9). In model 2, we present the treatment effect model along with the lambda parameter, which verifies the presence of endogeneity in the original model. Since the lambda coefficient is not significant, we cannot reject the OLS model (Note 10). Therefore, the evidence presented in model 1 is not driven by endogeneity of family management status (Note 11). This finding is consistent with empirical evidence that Italian family firms stick with 
their own management, even in economically hard times (Brunello, Graziano, \& Parigi, 2003; Volpin, 2002; Lippi \& Schivardi, 2010) (Note 12).

It is worth noting that the productivity differential between family management and outside management is not statistically significant when only family-owned firms are considered (model 2). That is, family firms show a similar level of efficiency regardless of the nature of the management team that runs the company.

Having estimated the base performance equation, we proceed to considering the impact of the institutional environment on firms TFP and introduce the IQI indicator (column 3). The coefficient shows that the quality of provincial government has a positive connection with firm's TFP. This result is in line with previous research that focused on the importance of institutions at the sub-national level (Tabellini, 2010; Ketterer \& Rodríguez-Pose 2016; Rodríguez-Pose \& Di Cataldo, 2014; Lasagni et al., 2015) (Note 13). Specifically for Italy, Lasagni et al. (2015) focused on the Institutional Quality Index for Italian provinces and found that local institution quality does matter, as it proves to be one of the main drivers of firm productivity differentials. Similar results were found by Manzocchi, Quintieri, \& Santoni (2014) and Aiello et al. (2014) when using different indicators (Note 14) and methodologies (Note 15). In model (3), the estimated parameters are invariant. However, when introducing the IQI indicator, the significance of the dummy variable for South disappears, so reflecting the fact that the majority of provinces located in the South of Italy show lower values of IQI.

We have shown that family-run firms are less productive than firms run by outside managers and that institutional efficiency affects TFP positively. The next step is to study whether the productivity gap between family and outside managers varies across different institutional contexts. To achieve this end, we estimate the regression in the same way as in model (1), but on the subsamples of provinces with low and high institutional efficiency (last two columns). Table 2 reveals that family management is only significantly associated with TFP in provinces with high institutional quality and that the relationship is negative: in more efficient institutional contexts, family managed firms perform worse than non-family managed firms. On the other hand in low-efficiency provinces, having a family manager has a neutral effect on a firm's performance. The inferior performance of Italian family managed firms as opposed to non-family managed firms (model 1 of table 2) appears to be driven by the provinces with high institutional efficiency. Family firms perform worse than non-family firms, but it seems that, in a context of low institutional efficiency, family governance helps firms to overcome some ill-functioning institutional environments and, thus, to offset the performance gap with non-family managed firms. This result is consistent with the proposition of Liu et al. (2012), which says that family firms will more significantly outperform non-family firms in an underdeveloped institutional environment than in a developed institutional environment.

The decomposition of the IQI indicator into its four basic components in table 3 shows a more heterogeneous representation of the interaction between family management and institutional quality. In table 3 , in order to discriminate the context in which firms operate considering the single aspects of the institutional quality, the sample is split into two for each component of the IQI, by considering the median value of the single indicator as separator of provinces in Low/High level. Higher values of sub-indices correspond to better institutions. However, the relative sub-index is computed so that it takes on higher values for lower levels of institutional quality when the focus is on the degree of corruption of individuals performing public functions (columns 1 and 2). As a consequence, the first column refers to the sample of companies located in provinces where corruption is high and the second column to the sample of provinces where it is low.

The decomposition of the IQI indicator confirms that family managed firms in a more efficient institutional context perform worse than non-family managed firms, when there is good administrative capacity (Government) and high ability to promote and protect the business activity (Regulatory Quality) of local government and in the presence of more efficient legal system and a lower propensity to the occurrence of crime or tax evasion (Rule of Law). However, the difference between family-managed and non-family managed firms disappears (the coefficient of the interaction family management-age is significant and positive) in provinces with high regulatory quality and an efficient legal system, when the experience of family-managed firms is taken in account.

Table 3 also shows that there is no difference in performance between firms with outside managers and those with family managers in an environment with a low level of corruption (Corruption) and strong social capital (Voice and Accountability). The opposite occurs in the provinces which have a marked presence of corruption and low social capital. The result regarding the proxy for social capital seems difficult to reconcile with the view that family-derived social capital (Arregle, Hitt, Sirmon, \& Very, 2007), privileged access to exclusive networks (Lester \& Cannella, 2006) and superior reputation (Dyer, 2006) are some of the difficult to imitate capabilities of "familiness" that allow family firms to develop competitive advantages (Gedajlovic et al., 2012). On this basis, we would have expected these family firm advantages to compensate for the lack of social capital and, consequently, 
the gap in performance between firms with family managers and those with outside managers to be null or positive in provinces with low institutional efficiency.

However, some authors stress that as families may tend to maximise the advantages of the nuclear family and assume that others do the same, the effect could be less trust and respect for others and less confidence in the individual (Note 16). For example, non-family employees may be treated as "second-class citizens" and exploited by the family and this may result in low employee morale and low productivity (Dyer, 2006). This view seems more compatible with our results.

Family managed firms perform worse than non-family managed firms in environments with a high level of corruption, (column 1). However, although this would certainly seem to be true for younger family managed firms, family managed firms that have been active in the territory for some time seem to cope better with high levels of corruption (the coefficient of the interaction family management-age is highly significant and positive).

We confirm that family firms may benefit from political connections in territories with high levels of corruption (Fisman, 2001; Faccio, 2006), but only if they have operated in the area for a long time.

Table 3. Family management and different dimensions of institutional quality

\begin{tabular}{|c|c|c|c|c|c|c|c|c|c|c|}
\hline & \multicolumn{2}{|c|}{ Corruption (a) } & \multicolumn{2}{|c|}{ Government Effectiveness } & \multicolumn{2}{|c|}{ Regulatory quality } & \multicolumn{2}{|c|}{ Rule of law } & \multicolumn{2}{|c|}{ Voice and accountability } \\
\hline & $\begin{array}{l}\text { High } \\
\text { (1) }\end{array}$ & $\begin{array}{l}\text { Low } \\
\text { (2) }\end{array}$ & $\begin{array}{l}\text { Low } \\
\text { (3) }\end{array}$ & $\begin{array}{l}\text { High } \\
\text { (4) }\end{array}$ & $\begin{array}{l}\text { Low } \\
\text { (5) }\end{array}$ & $\begin{array}{l}\text { High } \\
(6)\end{array}$ & $\begin{array}{l}\text { Low } \\
\text { (7) }\end{array}$ & $\begin{array}{l}\text { High } \\
(8)\end{array}$ & $\begin{array}{l}\text { Low } \\
\text { (9) }\end{array}$ & $\begin{array}{l}\text { High } \\
(10)\end{array}$ \\
\hline Family Management & $\begin{array}{l}-0.0690 * * \\
(0.030)\end{array}$ & $\begin{array}{l}-0.0254 \\
(0.019)\end{array}$ & $\begin{array}{l}-0.0187 \\
(0.038)\end{array}$ & $\begin{array}{l}-0.0395^{* *} \\
(0.019)\end{array}$ & $\begin{array}{l}-0.0224 \\
(0.031)\end{array}$ & $\begin{array}{l}-0.0462 * * \\
(0.019)\end{array}$ & $\begin{array}{l}-0.0479 \\
(0.032)\end{array}$ & $\begin{array}{l}-0.0377 * \\
(0.021)\end{array}$ & $\begin{array}{l}-0.0630 * * \\
(0.025)\end{array}$ & $\begin{array}{l}-0.0314 \\
(0.022)\end{array}$ \\
\hline Capital Intensity & $\begin{array}{l}0.0585^{* * *} \\
(0.015)\end{array}$ & $\begin{array}{l}0.0652^{* * *} \\
(0.013)\end{array}$ & $\begin{array}{l}0.1073 * * * \\
(0.020)\end{array}$ & $\begin{array}{l}0.0543^{* * *} \\
(0.011)\end{array}$ & $\begin{array}{l}0.0965^{* * *} \\
(0.018)\end{array}$ & $\begin{array}{l}0.0551^{* * *} \\
(0.011)\end{array}$ & $\begin{array}{l}0.0593 * * * \\
(0.020)\end{array}$ & $\begin{array}{l}0.0622 * * * \\
(0.013)\end{array}$ & $\begin{array}{l}0.0763^{* * *} \\
(0.013)\end{array}$ & $\begin{array}{l}0.0579 * * * \\
(0.012)\end{array}$ \\
\hline Age $(\log )$ & $\begin{array}{l}0.0258 \\
(0.022)\end{array}$ & $\begin{array}{l}0.0032 \\
(0.013)\end{array}$ & $\begin{array}{l}0.0653 * * \\
(0.032)\end{array}$ & $\begin{array}{l}0.0006 \\
(0.011)\end{array}$ & $\begin{array}{l}0.0680^{* * *} \\
(0.021)\end{array}$ & $\begin{array}{l}-0.0008 \\
(0.011)\end{array}$ & $\begin{array}{l}0.0333 \\
(0.021)\end{array}$ & $\begin{array}{l}0.0040 \\
(0.012)\end{array}$ & $\begin{array}{l}0.0060 \\
(0.019)\end{array}$ & $\begin{array}{l}0.0167 \\
(0.014)\end{array}$ \\
\hline Family Management *Age & $\begin{array}{l}0.1315^{* * *} \\
(0.038)\end{array}$ & $\begin{array}{l}0.0280 \\
(0.036)\end{array}$ & $\begin{array}{l}0.0870 \\
(0.070)\end{array}$ & $\begin{array}{l}0.0546 \\
(0.035)\end{array}$ & $\begin{array}{l}0.0574 \\
(0.040)\end{array}$ & $\begin{array}{l}0.0677 * \\
(0.038)\end{array}$ & $\begin{array}{l}0.0577 \\
(0.054)\end{array}$ & $\begin{array}{l}0.0673 * \\
(0.037)\end{array}$ & $\begin{array}{l}-0.0026 \\
(0.039)\end{array}$ & $\begin{array}{l}0.0878 * * \\
(0.035)\end{array}$ \\
\hline Size (log of employees) & $\begin{array}{l}0.2098^{* * *} \\
(0.015)\end{array}$ & $\begin{array}{l}0.2039^{* * *} \\
(0.009)\end{array}$ & $\begin{array}{l}0.2230 * * * \\
(0.022)\end{array}$ & $\begin{array}{l}0.2058^{* * * *} \\
(0.009)\end{array}$ & $\begin{array}{l}0.2257^{* * *} \\
(0.020)\end{array}$ & $\begin{array}{l}0.2010^{* * *} \\
(0.008)\end{array}$ & $\begin{array}{l}0.2041^{* * *} \\
(0.017)\end{array}$ & $\begin{array}{l}0.2053 * * * \\
(0.009)\end{array}$ & $\begin{array}{l}0.2015^{* * *} \\
(0.013)\end{array}$ & $\begin{array}{l}0.2080^{* * * *} \\
(0.011)\end{array}$ \\
\hline Equity concentration & $\begin{array}{l}0.0016^{* * *} \\
(0.000)\end{array}$ & $\begin{array}{l}0.0010^{* * *} \\
(0.000)\end{array}$ & $\begin{array}{l}0.0004 \\
(0.001)\end{array}$ & $\begin{array}{l}0.0013^{* * *} \\
(0.000)\end{array}$ & $\begin{array}{l}0.0009 * \\
(0.001)\end{array}$ & $\begin{array}{l}0.0013^{* * *} \\
(0.000)\end{array}$ & $\begin{array}{l}0.0007 * \\
(0.000)\end{array}$ & $\begin{array}{l}0.0014 * * * \\
(0.000)\end{array}$ & $\begin{array}{l}0.0003 \\
(0.000)\end{array}$ & $\begin{array}{l}0.0015^{* * *} \\
(0.000)\end{array}$ \\
\hline Listed firm & $\begin{array}{l}0.2224^{* * *} \\
(0.069)\end{array}$ & $\begin{array}{l}0.1188^{* *} \\
(0.059)\end{array}$ & $\begin{array}{l}0.2319 \\
(0.283)\end{array}$ & $\begin{array}{l}0.1500^{* * *} \\
(0.043)\end{array}$ & $\begin{array}{l}0.1994 \\
(0.160)\end{array}$ & $\begin{array}{l}0.1609 * * * \\
(0.044)\end{array}$ & $\begin{array}{l}0.1737 * \\
(0.088)\end{array}$ & $\begin{array}{l}0.1611^{* * *} \\
(0.058)\end{array}$ & $\begin{array}{l}0.2115 * \\
(0.124)\end{array}$ & $\begin{array}{l}0.1610^{* * *} \\
(0.045)\end{array}$ \\
\hline Human capital & $\begin{array}{l}0.3696^{* * *} \\
(0.044)\end{array}$ & $\begin{array}{l}0.2116^{* * *} \\
(0.028)\end{array}$ & $\begin{array}{l}0.3017 * * * \\
(0.081)\end{array}$ & $\begin{array}{l}0.2606^{* * * *} \\
(0.031)\end{array}$ & $\begin{array}{l}0.3532 * * * \\
(0.051)\end{array}$ & $\begin{array}{l}0.2387 * * * \\
(0.034)\end{array}$ & $\begin{array}{l}0.3228 * * * \\
(0.063)\end{array}$ & $\begin{array}{l}0.2444 * * * \\
(0.035)\end{array}$ & $\begin{array}{l}0.2329 * * * \\
(0.055)\end{array}$ & $\begin{array}{l}0.2824 * * * \\
(0.032)\end{array}$ \\
\hline South & $\begin{array}{l}-0.1383^{* * *} \\
(0.038)\end{array}$ & $\begin{array}{l}-0.1730 * * * \\
(0.050)\end{array}$ & $\begin{array}{l}-0.1205^{*} \\
(0.061)\end{array}$ & & $\begin{array}{l}-0.0926^{* * * *} \\
(0.029)\end{array}$ & $\begin{array}{l}-0.1241 * * * \\
(0.018)\end{array}$ & $\begin{array}{l}-0.1230 * * * \\
(0.031)\end{array}$ & $\begin{array}{l}-0.1347 * * * \\
(0.031)\end{array}$ & $\begin{array}{l}-0.0932^{* * * *} \\
(0.031)\end{array}$ & $\begin{array}{l}-0.2156^{* * *} \\
(0.061)\end{array}$ \\
\hline Center & $\begin{array}{l}-0.0815^{*} \\
(0.043)\end{array}$ & $\begin{array}{l}-0.0043 \\
(0.035)\end{array}$ & $\begin{array}{l}-0.0762 \\
(0.068)\end{array}$ & $\begin{array}{l}-0.0119 \\
(0.033)\end{array}$ & $\begin{array}{l}-0.0144 \\
(0.033)\end{array}$ & $\begin{array}{l}-0.0232 \\
(0.037)\end{array}$ & $\begin{array}{l}-0.0560^{* *} \\
(0.026)\end{array}$ & $\begin{array}{l}-0.0405 \\
(0.033)\end{array}$ & $\begin{array}{l}-0.0669^{*} \\
(0.033)\end{array}$ & $\begin{array}{l}-0.0263 \\
(0.034)\end{array}$ \\
\hline Pavitt 2 & $\begin{array}{l}0.1787^{* * *} \\
(0.035)\end{array}$ & $\begin{array}{l}0.1095^{* * *} \\
(0.023)\end{array}$ & $\begin{array}{l}0.2082 * * * \\
(0.050)\end{array}$ & $\begin{array}{l}0.1190^{* * * *} \\
(0.024)\end{array}$ & $\begin{array}{l}0.1450^{* * *} \\
(0.045)\end{array}$ & $\begin{array}{l}0.1333 * * * \\
(0.024)\end{array}$ & $\begin{array}{l}0.1949 * * * \\
(0.037)\end{array}$ & $\begin{array}{l}0.1096^{* * *} \\
(0.026)\end{array}$ & $\begin{array}{l}0.1521^{* * *} \\
(0.038)\end{array}$ & $\begin{array}{l}0.1177 * * * \\
(0.025)\end{array}$ \\
\hline Pavitt 3 & $\begin{array}{l}0.1731^{* * *} \\
(0.027)\end{array}$ & $\begin{array}{l}0.1269^{* * *} \\
(0.021)\end{array}$ & $\begin{array}{l}0.1734 * * \\
(0.065)\end{array}$ & $\begin{array}{l}0.1364 * * * \\
(0.018)\end{array}$ & $\begin{array}{l}0.1974 * * * \\
(0.052)\end{array}$ & $\begin{array}{l}0.1304 * * * \\
(0.019)\end{array}$ & $\begin{array}{l}0.1791 * * * \\
(0.036)\end{array}$ & $\begin{array}{l}0.1241^{* * * *} \\
(0.020)\end{array}$ & $\begin{array}{l}0.1696^{* * *} \\
(0.034)\end{array}$ & $\begin{array}{l}0.1206^{* * * *} \\
(0.019)\end{array}$ \\
\hline Pavitt 4 & $\begin{array}{l}0.1995^{* * *} \\
(0.037)\end{array}$ & $\begin{array}{l}0.1847^{* * *} \\
(0.049)\end{array}$ & $\begin{array}{l}0.2603^{* *} \\
(0.117)\end{array}$ & $\begin{array}{l}0.1793^{* * * *} \\
(0.039)\end{array}$ & $\begin{array}{l}0.1291 * * \\
(0.060)\end{array}$ & $\begin{array}{l}0.2034 * * * \\
(0.039)\end{array}$ & $\begin{array}{l}0.0718 \\
(0.045)\end{array}$ & $\begin{array}{l}0.2058^{* * * *} \\
(0.040)\end{array}$ & $\begin{array}{l}0.1813 * * \\
(0.088)\end{array}$ & $\begin{array}{l}0.1722^{* * *} \\
(0.043)\end{array}$ \\
\hline Constant & $\begin{array}{l}6.6352^{* * * *} \\
(0.025)\end{array}$ & $\begin{array}{l}6.6267^{* * *} \\
(0.011)\end{array}$ & $\begin{array}{l}6.5932 * * * \\
(0.040)\end{array}$ & $\begin{array}{l}6.6494 * * * \\
(0.014)\end{array}$ & $\begin{array}{l}6.5875^{* * *} \\
(0.011)\end{array}$ & $\begin{array}{l}6.6402 * * * \\
(0.014)\end{array}$ & $\begin{array}{l}6.6123^{* * *} \\
(0.015)\end{array}$ & $\begin{array}{l}6.6383 * * * \\
(0.015)\end{array}$ & $\begin{array}{l}6.5813^{* * *} \\
(0.015)\end{array}$ & $\begin{array}{l}6.6416^{* * *} \\
(0.015)\end{array}$ \\
\hline Observations & 822 & 1,606 & 404 & 2,024 & 521 & 1,907 & 709 & 1,719 & 719 & 1,709 \\
\hline R-squared & 0.378 & 0.321 & 0.364 & 0.332 & 0.413 & 0.319 & 0.387 & 0.319 & 0.308 & 0.350 \\
\hline
\end{tabular}

Robust standard errors in parentheses. Level of significance: *** $1 \%$;* $5 \%$; * $10 \%$.

\subsection{Robustness Checks}

In order to check the robustness of our results, we complement the analysis by considering a different measure of firm performance and other indicators of institutional quality. 
The first robustness check entails estimating equation (1) by considering labour productivity as a dependent variable and using the IQI to collapse the provinces into the two groups, low and high. As indicated in Table 4 (columns 1 and 2), the results regarding the gap between family and outside managers in the two institutional environments are qualitatively the same than when TFP is used (Table 3 columns 4 and 5).

Next, we examine whether our previous results on the interaction of family management and institutional quality are robust to the use of two different measures of institutional quality based on subjective survey aggregated at the regional level (NUTS 2).

The first of these measures is the European "quality of government" indicator (EQI), developed by Charron et al. (2014). This study involves a large survey of 34,000 Europeans which focuses on the quality, impartiality and level of corruption in public education, public health care and law enforcement, services often provided by local authorities in Europe. The main idea is that regional governments are more effective if they are capable of ensuring equality of access to the services they offer. The quality of regional government (QoG) has been integrated into the World Bank Governance Indicator (WGI). In particular, the regional QoG score for each country is aggregated by weighting each region's score by their share of the national population. This mean score is subtracted from each region's individual QoG score and the value obtained shows whether the region is above or below its national average and by how much. This figure is then added to the national level of the WGI, so each region has an adjusted score which is centered on the WGI. The QoG is standardised for the EU-27 sample so that the mean is zero with a standard deviation of one, obtaining the European Quality Index (EQI) (Note 17). In this study we consider the EQI indicator for the 20 regions of Italy. In order to divide the Italian regions into the two groups, low and high, we refer to the value of Italy and group the regions with a lower (higher) EQI value than the national value into low (high) institutional environment (Note 18).

The second indicator refers to the measure of trust obtained by Tabellini (2010) and aggregates individual responses collected at the regional level in World Value Survey opinion polls of the 1990s. In particular, the percentage of respondents who answer "Most people can be trusted" (Note 19) to the following question:

"Generally speaking, would you say that most people can be trusted or that you can't be too careful in dealing with people?" (Note 20).

Table 4 reports the results when the sample is split into two on the basis of the EQI ranking (columns 3 and 4 ) and the trust indicator (col 5 and 6) (Note 21). As in previous results (table 2), these checks confirm that family managed firms perform worse than non-family managed firms in a more efficient institutional context while there is no difference in low-efficiency provinces. However, the performance gap between family and outside managers in high quality institutional environments tends to disappear in the case of older family firms.

Table 4. Robustness checks

\begin{tabular}{lllllll}
\hline & \multicolumn{2}{c}{ Labour productivity } & \multicolumn{2}{l}{ EQI } & \multicolumn{2}{l}{ TRUST } \\
\hline & Low & High & Low & High & Low & $(6)$ \\
\hline Family Management & $(1)$ & $(2)$ & $(3)$ & $(4)$ & $(5)$ & $-0.0502^{* *}$ \\
& -0.0505 & $-0.0405^{*}$ & -0.0266 & $-0.0411^{* *}$ & -0.0235 & $(0.019)$ \\
Capital Intensity & $(0.041)$ & $(0.022)$ & $(0.048)$ & $(0.018)$ & $(0.029)$ & $0.0660^{* * *}$ \\
& $0.1011^{* * *}$ & $0.0680^{* * *}$ & $0.0835^{* * *}$ & $0.0596^{* * *}$ & $0.0533^{* * *}$ & $(0.014)$ \\
Age (log) & $(0.021)$ & $(0.012)$ & $(0.028)$ & $(0.011)$ & $(0.019)$ & 0.0063 \\
& 0.0497 & 0.0021 & $0.0985^{* *}$ & 0.0057 & 0.0343 & $(0.012)$ \\
Family Management*Age & $(0.040)$ & $(0.016)$ & $(0.043)$ & $(0.011)$ & $(0.023)$ & $0.0705^{*}$ \\
& 0.0839 & 0.0625 & 0.0405 & $0.0633^{*}$ & 0.0629 & $(0.038)$ \\
Size (log of employees) & $(0.066)$ & $(0.039)$ & $(0.084)$ & $(0.033)$ & $(0.050)$ & $0.2056^{* * *}$ \\
& 0.0349 & $0.0160^{*}$ & $0.2182^{* * *}$ & $0.2047^{* * *}$ & $0.2099^{* * *}$ & $(0.010)$ \\
Equity concentration & $(0.024)$ & $(0.008)$ & $(0.038)$ & $(0.008)$ & $(0.015)$ & $0.0010^{* *}$ \\
& -0.0006 & $0.0013^{* * *}$ & 0.0007 & $0.0012^{* * *}$ & $0.0016^{* * *}$ & $(0.000)$ \\
Listed firm & $(0.001)$ & $(0.000)$ & $(0.001)$ & $(0.000)$ & $(0.000)$ & $0.1452^{* *}$ \\
Human capital & $0.4033^{* * *}$ & 0.0045 & 0.4021 & $0.1476^{* * *}$ & $0.1706^{* *}$ & $(0.055)$ \\
& $(0.139)$ & $(0.068)$ & $(0.291)$ & $(0.044)$ & $(0.084)$ & $0.2595^{* * *}$ \\
South & $0.2978^{* * *}$ & $0.1980^{* * *}$ & $0.4716^{* * *}$ & $0.2503^{* * *}$ & $0.3151^{* * *}$ & $(0.036)$ \\
Center & $(0.078)$ & $(0.033)$ & $(0.096)$ & $(0.031)$ & $(0.056)$ & 0.1350 \\
& -0.0467 & & & $-0.1615^{* * *}$ & $-0.2426^{* * *}$ & $(0.142)$ \\
& $(0.046)$ & & & $(0.037)$ & $(0.032)$ & $-0.0723^{* *}$ \\
& -0.0253 & -0.0041 & 0.0619 & -0.0330 & $-0.0884^{* *}$ & $(0.029)$ \\
\hline
\end{tabular}




\begin{tabular}{|c|c|c|c|c|c|c|}
\hline Pavitt 2 & $\begin{array}{l}0.1700 * * * \\
(0.056)\end{array}$ & $\begin{array}{l}0.1030 * * * \\
(0.022)\end{array}$ & $\begin{array}{l}0.1848 * \\
(0.095)\end{array}$ & $\begin{array}{l}0.1322 * * * \\
(0.022)\end{array}$ & $\begin{array}{l}0.1325 * * * \\
(0.038)\end{array}$ & $\begin{array}{l}0.1291 * * * \\
(0.028)\end{array}$ \\
\hline Pavitt 3 & $\begin{array}{l}0.1815 * * * \\
(0.058)\end{array}$ & $\begin{array}{l}0.1080 * * * \\
(0.021)\end{array}$ & $\begin{array}{l}0.1813^{* *} \\
(0.088)\end{array}$ & $\begin{array}{l}0.1409 * * * \\
(0.018)\end{array}$ & $\begin{array}{l}0.0397 \\
(0.032)\end{array}$ & $\begin{array}{l}0.1745^{* * *} \\
(0.018)\end{array}$ \\
\hline Pavitt 4 & $\begin{array}{l}0.2708^{* *} \\
(0.119)\end{array}$ & $\begin{array}{l}0.0829 * * * \\
(0.030)\end{array}$ & $\begin{array}{l}0.0622 \\
(0.069)\end{array}$ & $\begin{array}{l}0.2020 * * * \\
(0.037)\end{array}$ & $\begin{array}{l}0.0528 \\
(0.043)\end{array}$ & $\begin{array}{l}0.2388^{* * * *} \\
(0.042)\end{array}$ \\
\hline Constant & $\begin{array}{l}6.1314 * * * \\
(0.033)\end{array}$ & $\begin{array}{l}6.2455^{* * *} \\
(0.013)\end{array}$ & $\begin{array}{l}6.5506 * * * \\
(0.028)\end{array}$ & $\begin{array}{l}6.6293 * * * \\
(0.013)\end{array}$ & $\begin{array}{l}6.6955 * * * \\
(0.015)\end{array}$ & $\begin{array}{l}6.6371 * * * \\
(0.021)\end{array}$ \\
\hline Observations & 439 & 1,873 & 208 & 2,220 & 750 & 1,678 \\
\hline R-squared & 0.164 & 0.089 & 0.381 & 0.333 & 0.372 & 0.338 \\
\hline
\end{tabular}

Robust standard errors in parentheses. Level of significance: *** $1 \%$; * $5 \%$; * $10 \%$.

\section{Conclusions}

Studies of family firms have increased over the past decades but much existing research focuses upon factors which are internal to family firms. The relationship between national institutions and performance is a growing area of research, much of which lines up under the banner of the institution-based view of business strategy. A basic forecast of this literature is that family firms will be prevalent in a context where there are underdeveloped legal frameworks and inefficient public administration. More generally, family firms, with their competitive advantages relating to social capital and relational contracting, can outperform non-family firms because this relational capital helps firms fill institutional voids (Miller et al., 2009).

However, the literature on the costs and benefits of family firms' advantages which arise from relational contracting in institutionally less developed environments is divided. Some authors hold the opinion that relational contracting is beneficial and indicate a capacity for filling institutional voids (Miller et al., 2009), while others believe that relational contracting is associated with cronyism (James, 2008) and rent-seeking (Morck \& Yeung, 2004).

The present paper contributes to this strand of literature by investigating the influence that differences in local institutional quality have in shaping the gap between family and non- family firms' TFP in a developed economy such as Italy.

Our main results can be summarised as follows.

First, we provide further evidence that the quality of local institutions plays an important role in explaining firm productivity in Italy. In fact, our results show that the existence of better quality local institutions might help firms to become more productive.

Second, we find that family-run firms are less productive that firms run by outside managers in high quality institutional environments, after controlling for sector, area, age, listing on the Stock Exchange, human capital, capital intensity and ownership concentration. Indeed, a high quality institutional environment enhances the degree of technological dynamism in the economy. In this contest, the competitive advantage of family businesses due to the importance of human relationships in business life weakens, social connections built by relatives in the past are more likely to become obsolete and their transfer across generations is less productive.

Third, when the institutional environment is weak, the difference in performance between firms run by a family member and firms run a by a professional manager vanishes. Consequently, the better performance of non-family firms is negated, so confirming the proposition of Liu et al. (2012) that family firms will more significantly outperform non-family firms in an underdeveloped institutional environment than in a developed institutional environment. However, when considering the sub index of corruption, we find that when the socio-cultural structure is corrupt, only younger family managed firms underperform non-family firms. On the other hand, family managed firms which have been active in the territory for a long time seem to benefit from high corruption. In fact, older family firms may have a special relationship with political power given that it is preferable for politicians to grant aid to companies who have long term horizons and whose ownership is stable, rather than assist companies with a high turnover of control. Stable companies can then return the favour. These connections with politicians may result in aid and subsidies, contracts to supply the public administration and favourable rules and regulations (Morck et al., 2000; Faccio, 2006), all of which contribute to superior firm performance but, at the same time, slow the process of development down in the territories where these firms operate. 


\section{References}

Accetturo, A., Bassanetti, A., Bugamelli, M., Faiella, I., Finaldi Russo, P., Franco, D., \& Omiccioli, M. (2013). Il sistema industriale italiano tra globalizzazione e crisi. Questioni di Economia e Finanza (Occasional Papers), No 193, Bank of Italy, Rome.

Acemoglu, D., \& Robinson, J. A. (2008). The role of institution in growth and development. Commission on growth and development, Working Paper No. 10.

Aguilera, R. V., \& Crespi-Cladera, R. (2012). Firm family firms: Current debates of corporate governance in family firms. Journal of Family Business Strategy, 3, 66-69. http://dx.doi.org/10.1016/j.jfbs.2012.03.006

Aiello, F., Pupo, V., \& Ricotta F. (2014). Explaining Total Factor Productivity at firm level in Italy: Does location matter? Spatial Economic Analysis, 9 (1), 1-20.

Aiello, F., Pupo, V., \& Ricotta, F. (2009). Sulla dinamica della Produttività Totale dei Fattori in Italia. Un'analisi settoriale. L'Industria-Rivista di Economia E Politica Industriale, 3, 405-426. http://dx.doi.org/10.1080/17421772.2013.863428

Aiello, F., Pupo, V., \& Ricotta, F. (2012). A territorial analysis of TFP in Italy. Scienze Regionali-Italian Journal of Regional Science, 11(2), 23-46.

Amit, R., Ding, Y., Villalonga, B., \& Zhang, H. (2015). The role of institutional development in the prevalence and performance of entrepreneur and family-controlled firms. Journal of Corporate Finance, 31, 284-305. http://dx.doi.org/10.1016/j.jcorpfin.2015.01.001

Anderson, R. C., \& Reeb, D. (2003). Founding-family owner and firm performance: Evidence from the S\&P500. Journal of Finance, 58, 1302-1328. http://dx.doi.org/10.1111/1540-6261.00567

Andres, C. (2008). Large shareholders and firm performance. An empirical examination of founding-family ownership. Journal of Corporate Finance, 4, 431-445. http://dx.doi.org/10.1016/j.jcorpfin.2008.05.003

Arosa, B., Iturralde, T., \& Maseda, A. (2010). Ownership structure and firm performance in non-listed firms: Evidence from Spain. Journal of Family Business Strategy, 1(2), 88-96. http://dx.doi.org/10.1016/j.jfbs.2010.03.001

Arregle, J., Hitt, M. A., Sirmon, D. G., \& Very, P. (2007). The Development of organizational social capital: Attributes of family firms. Journal of Management Studies, 44(1), 73-95. http://dx.doi.org/10.1111/j.1467-6486.2007.00665.x

Ascari, G., \& Di Cosmo, V. (2005). Determinants of Total Factor Productivity in the Italian Regions." Scienze Regionali-Italian Journal of Regional Science, 4, $27-49$.

Banalieva, E. A., Eddleston, K. A., \& Zellweger, T. M. (2015). When do family firms have an advantage in transitioning economies? Toward a dynamic institution based view. Strategic Management Journal, 36, 1358-1377. http://dx.doi.org/10.1002/smj.2288

Banfield, E. C. (1958). The moral basis of a backward societ. New York: The Free Press.

Barney, J. (1991). Firm resources and sustained competitive advantage. Journal of Management, 17, 99-120. http://dx.doi.org/10.1177/014920639101700108

Barontino, R., \& Caprio, I. (2006). The effect of family control on firm value and performance: Evidence from $\begin{array}{lllll}\text { Continental Europe. European Financial Management, } & \text { 12, }\end{array}$ http://dx.doi.org/10.1111/j.1468-036X.2006.00273.x

Barth, E., Gulbrandsen, T., \& Schøne P. (2005). Family ownership and productivity: The role of $\begin{array}{lllll}\text { owner-management. Journal of Corporate } & \text { Finance, 11, }\end{array}$ http://dx.doi.org/10.1016/j.jcorpfin.2004.02.001

Bassanetti, A., Iommi, M., Jona-Lasinio, C., \& Zollino, F. (2004). La crescita dell'economia italiana negli anni novanta tra ritardo tecnologico e rallentamento della produttività. Temi di Discussione, No 539, Banca d'Italia, Roma.

Block, J., Jaskiewicz, R., \& Miller, D. (2011). Ownership versus management effects on performance in family and founder companies: A bayesian reconciliation. Journal of Family Business Strategy, 2(4), 232-245. http://dx.doi.org/10.1016/j.jfbs.2011.10.001

Bloom, N., \& Van Reenen, J. (2007). Measuring and explaining management practices across firms and countries. The Quarterly Journal of Economics, 122, 1351-1408. 
http://dx.doi.org/10.1162/qjec.2007.122.4.1351

Bloom, N., Sadun, R., \& Van Reenen, J. (2008). Measuring and explaining management practices in Italy. Rivista di Politica Economica, 98( 2), 15-56.

Brealey, R. A., \& Myers, S. C. (2000). Principles of Corporate Finance. (6th edn) .New York McGraw-Hill.

Brunello, G., Graziano, C., \& Parigi, B. M. (2003). CEO turnover in insider dominated boards: The Italian case. Journal of Banking and Finance, 27, 1027-1051. http://dx.doi.org/10.1016/S0378-4266(02)00244-3

Byrne, J. P., Fazio, G., \& Piacentino, D. (2009). Total Factor Productivity convergence among Italian Regions: Some evidence from panel unit root tests. Regional Studies, 43(1), 63-76. http://dx.doi.org/10.1080/00343400701654137

Carney, M. (2005). Corporate governance and competitive advantage in family-controlled firms. Entrepreneurship Theory \& Practice, 29(3), 249-265. http://dx.doi.org/10.1111/j.1540-6520.2005.00081.x

Carney, M., \& Gedajlovic, E. (2002). The co-evolution of institutional environments and organizational strategies: The rise of family business groups in the ASEAN region. Organization Studies, 23(1), 1-29. http://dx.doi.org/10.1177/0170840602231001

Carney, M., Gedajlovic, E. R., Heugens, P. P. M. A. R., Van Essen, M., \& Van Oosterhout, J. (2011). Business group affiliation, performance, context, and strategy: A meta-analysis. Academy of Management Journal, 54(3), 437-460. http://dx.doi.org/10.5465/AMJ.2011.61967812

Carney, M., van Essen, M., Gedajlovic, E. R., \& Heugens, P. P. M. A. R. (2015). What do we know about private family firms? A meta-analytical review. Entrepreneurship Theory and Practice, 513-544. http://dx.doi.org/10.1111/etap.12054

Chanda, A., \& Dalgaard, C. J. (2008). Dual economies and international total factor productivity differences: Channelling the impact from institutions, trade, and geography. Economica, 75(300), 629-661. http://dx.doi.org/10.1111/j.1468-0335.2007.00673.x

Chang, E. P. C., Chrisman, J. J., Chua, J. H., \& Kellermanns, F. W. (2008). Regional economy as a determinant of the prevalence of family firms in the United States: A preliminary report. Entrepreneurship Theory and Practice, 32(3), 559-573. http://dx.doi.org/10.1111/j.1540-6520.2008.00241.x

Charron, N., Djkstra, L., \& Lapuente, V. (2014). Regional governance matters: Quality of government within European Union Member States. Regional Studies, 48 (1), 68-90. http://dx.doi.org/10.1080/00343404.2013.770141

Chrisman, J. J., Kellermanns, F. W., Chan, K. C., \& Liano, K. (2010). Intellectual foundations of current research in family business: An identification and review of 25 influential articles. Family Business Review, 23, 9-26. http://dx.doi.org/10.1177/0894486509357920

Cohen, W. M., \& Levinthal, D. A. (1990). Absorptive capacity: A new perspective of learning and innovation. Administrative Science Quarterly, 35, 128-152. http://dx.doi.org/10.2307/2393553

Cong, R., \& Drukker, D. M. (2000). Treatment effects model. Stata Technical Bulletin, May.

Cucculelli, M., \& Marchionne, F. (2012). Market opportunities and owner identity: Are family firms different? Journal of Corporate Finance, 18, 476-495. http://dx.doi.org/10.1016/j.jcorpfin.2012.02.001

Cucculelli, M., \& Micucci, G. (2008). Family succession and firm performance: Evidence from Italian firms. Journal of Corporate Finance, 14, 17-31. http://dx.doi.org/10.1016/j.jcorpfin.2007.11.001

Cucculelli, M., Mannarino, L., Pupo, V., \& Ricotta, F. (2014). Owner-management, firm age, and productivity in Italian family firms. Journal of Small Business Management, 52(2), 325-343. http://dx.doi.org/10.1111/jsbm.12103

Daveri, F., \& Jona Lasinio, C. (2005). Italy's decline: getting the facts right. Giornale degli Economisti e Annali di Economia, 64(4), 365-410. http://dx.doi.org/10.2139/ssrn.871039

Di Liberto, A., \& Sideri, M. (2015). Past dominations, current institutions and the Italian regional economic performance. European Journal of Political Economy, $38,41$. http://dx.doi.org/10.1016/j.ejpoleco.2014.12.006

Dyer, W. G. Jr. (2006). Examining the "family effect" on firm performance. Family Business Review, 19, 253-273. http://dx.doi.org/10.1111/j.1741-6248.2006.00074.x 
Ellington, E. P., Jones, R. T., \& Deane, R. (1996). Tqm adoption practices in family-owned business. Family Business Review, 9, 5-14. http://dx.doi.org/10.1111/j.1741-6248.1996.00005.x

Faccio, M. (2006). Politically connected Firms. American Economic Review, 96(1), 369-386. http://dx.doi.org/10.1257/000282806776157704

Faccio, M., \& Lang, L. (2002). The ultimate ownership of Western European corporations. Journal of Financial Economics, 65, 365-395. http://dx.doi.org/10.1016/S0304-405X(02)00146-0

Fisman, R. (2001). Estimating the value of political connections. American Economic Review, 91(4), 1095-1102. http://dx.doi.org/10.1257/aer.91.4.1095

Garcia-Castro, R., \& Aguilera, R. V. (2014). Family involvement in business and financial performance: A set-theoretic cross-national inquiry. Journal of Family Business Strategy, 5(1), 85-96. http://dx.doi.org/10.1016/j.jfbs.2014.01.006

Gedajlovic, E., Carney, M., Chrisman, J. J., \& Kellermanns, F. W. (2012). The adolescence of family firm research: Taking stock and planning for the future. Journal of Management, 38(4), 1010-1037. http://dx.doi.org/10.1177/0149206311429990

Gilson, R. J. (2007). Controlling family shareholders in developing countries: Anchoring relational exchange. Stanford Law Review, 60(2), 633-656. http://dx.doi.org/10.2139/ssrn.957895

Golden, M., \& Picci, L. (2005). Proposal for a new measure of corruption, illustrated with Italian data. Economics \& Politics, 17, 37-75. http://dx.doi.org/10.1111/j.1468-0343.2005.00146.x

Gómez-Mejía, L. R., Nunez-Nickel, M., \& Gutierrez, I. (2001). The role of family ties in agency contracts. Academy of Management Journal, 44(1), 81-95. http://dx.doi.org/10.2307/3069338

Greene, W. H. (2000). Econometric Analysis. 4th ed. Upper Saddle River, NJ: Prentice-Hall.

Griffell-Tatje, E., \& Lovell, C. A. K. (1999). Profits and productivity. Management Science, 45, 1177-1193. http://dx.doi.org/10.1287/mnsc.45.9.1177

Habbershon, T. G., \& Williams, M. L. (1999). A resource-based framework for assessing the strategic advantages of family firms. Family Business Review, 12, 1-25. http://dx.doi.org/10.1111/j.1741-6248.1999.00001.x

Hart, O. (2001). Financial contracting. Journal of Economic Literature, 39, 1079-1100. http://dx.doi.org/10.1257/jel.39.4.1079

James, H. (2008). Family values or crony capitalism? Capitalism and Society, 3(2), 1-27. http://dx.doi.org/10.2202/1932-0213.1031

Kaufmann, D., Kraay, A., \& Mastruzzi, M. (2010). The worldwide governance indicators: Methodology and analytical issues. Policy Research Working Paper Series, No 5430. Washington, DC: The World Bank.

Ketterer, T. D., \& Rodríguez-Pose, A. (2016). Institutions vs. 'first-nature' geography - What drives economic growth in Europe's regions? Papers in Regional Science. http://dx.doi.org/10.1111/pirs.12237

La Porta, R., Lopez De Silanes, F., \& Shleifer, A. (1999). Corporate ownership around the world. Journal of Finance, 54, 471-517. http://dx.doi.org/10.1111/0022-1082.00115

Lasagni, A., Nifo, A., \& Vecchione, G. (2015). Firm productivity and institutional quality: Evidence from Italian industry. Journal of Regional Science, 55(5), 774-800. http://dx.doi.org/10.1111/jors.12203

Lee, J. (2006). Family firm performance: Further evidence. Family Business Review, 2, 103-114. http://dx.doi.org/10.1111/j.1741-6248.2006.00060.x

Lester, R. H., \& Cannella, A. A. (2006). Interorganizational familiness: How family firms use interlocking directorates to build community-level social capital. Entrepreneurship Theory and Practice, 30, 755-775. http://dx.doi.org/10.1111/j.1540-6520.2006.00149.x

Levinshon, J., \& Petrin, A. (2003). Estimating production functions using inputs to control for unobservables. Review of Economic Studies, 70, 317-341. http://dx.doi.org/10.1111/1467-937X.00246

Lippi, F., \& Schivardi, F. (2010). Corporate ownership and managers' selection. CEPR Discussion Paper DP8031.

Liu, W., Yang, H., \& Zhang, G. (2012). Does family business excel in firm performance? An institution-based view. Asia Pacific Journal of Management, 29(4), 965-987. http://dx.doi.org/10.1007/s10490-010-9216-6

Loayza, N. V., Oviedo, A. M., \& Serven, L. (2005). The impact of regulation on growth and 
informality-cross-country evidence. Policy Research Working Paper Series No 3623, The World Bank. http://dx.doi.org/10.1596/1813-9450-3623

Lumpkin, G. T., Steier, L., \& Wright, M. (2011). Strategic entrepreneurship in family business. Strategic Entrepreneurship Journal, 5, 285-306. http://dx.doi.org/10.1002/sej.122

Manzocchi, S., Quintieri, B., \& Santoni, G. (2014). Internal vs. external firm productivity drivers. A study of the Italian counties. LUISS Lab Working Papers, Roma: LLEE Luiss.

Maury, B. (2006). Family ownership and firm performance: Empirical evidence from western european corporations. Journal of Corporate Finance, 12, 321-341. http://dx.doi.org/10.1016/j.jcorpfin.2005.02.002

Mazzi, C. (2011). Family business and financial performance: Current state of knowledge and future research challenges. Journal of Family Business Strategy, 2(3), 166-181. http://dx.doi.org/10.1016/j.jfbs.2011.07.001

McConaughy, D., Matthews, C., \& Fialko, A. S. (2001). Founding family controlled firms: Efficiency, risk, and value. Journal of Small Business Management, 39 (1), 31-50. http://dx.doi.org/10.1111/0447-2778.00004

McGuinness, A. (2007). Institutions and Total Factor Productivity convergence, Working Paper, Central Bank and Financial Services Authority of Ireland.

Miller, D., Breton-Miller, I., Lester, R., \& Cannella, A. (2007). Are family firms really superior performers?. Journal of Corporate Finance, 13, 829-858.

Miller, D., Le Breton-Miller, I., \& Scholnick, B. (2008). Stewardship vs. Stagnation: An Empirical Comparison of Small Family and Non-Family Businesses. Journal of Management Studies, 45 (1), 51-78. http://dx.doi.org/10.1057/jibs.2009.11

Miller, D., Lee, J., Chang, S., \& Le Breton-Miller, I. (2009). Filling the institutional void: the social behavior and performance of family versus non-family technology firms in emerging markets. Journal of International Business Studies, 40 (5), 802-817. http://dx.doi.org/10.1016/j.jcorpfin.2007.03.004

Morck, R. K., \& Yeung, B. (2004). Family control and the rent-seeking society. Entrepreneurship Theory and Practice, 28 (4), 391-409. http://dx.doi.org/10.1111/j.1540-6520.2004.00053.x

Morck, R. K., Stangeland, D. A., \& Yeung, B. (2000). Inherited wealth, corporate control, and economic growth. In R. K. Morck (Ed.), Concentrated Corporate Ownership. NBER Conference Volume, Chicago, Chicago University Press. http://dx.doi.org/10.7208/chicago/9780226536828.001.0001

Nifo, A., \& Vecchione, G. (2014). Do institutions play a role in skilled migration? The case of Italy. Regional Studies, 48 (10), 1628-1649. http://dx.doi.org/10.1080/00343404.2013.835799

O'Boyle, Jr. E. H., Pollack, J. M., \& Rutherford, M. W. (2012). Exploring the relation between family involvement and firms' financial performance: A meta-analysis of main and moderator effects. Journal of Business Venturing, 27, 1-18. http://dx.doi.org/10.1016/j.jbusvent.2011.09.002

OECD. (2007). Economic Survey: Italy, OECD, Paris.

Palia, D., \& Lichtenberg, F. (1999). Managerial ownership and firm performance: A re-examination using

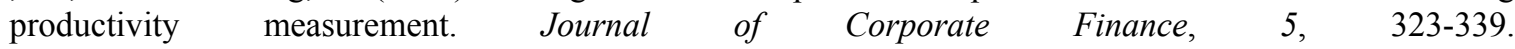
http://dx.doi.org/10.1016/S0929-1199(99)00009-7

Peng, M. W., \& Jiang, Y. (2010). Institutions behind family ownership and control in large firms. Journal of Management Studies, 47(2), 253-273. http://dx.doi.org/10.1111/j.1467-6486.2009.00890.x

Pindado, J., Requejo, I., \& Torre, C. (2008). Does family ownership impact positively on firm value? Empirical evidence from Western Europe. Working Papers "New Trends on Business Administration", Universities of Valladolid, Burgos, Salamanca and León, Spain.

Putnam, R. D. (1993). Making democracy work: Civic traditions in modern Italy. Princeton University Press, Princeton, NJ

Rodríguez-Pose, A., \& Di Cataldo, M. (2014). Quality of government and innovative performance in the regions of Europe. Journal of Economic Geography. http://dx.doi.org/10.1093/jeg/lbu023

Rodrik, D., Subramanian, A., \& Trebbi, F. (2004). Institutions rule: The primacy of institutions over geography and integration in economic development. Journal of Economic Growth, 9, 131-165. http://dx.doi.org/10.1023/B:JOEG.0000031425.72248.85

Rutherford, M., Kuratko, D., \& Holt, D. (2008). Examining the link between "familiness" and performance: Can 
the F-PEC untangle the family business theory jungle? Entrepreneurship Theory and Practice, 32(6), 1089-1109. http://dx.doi.org/10.1111/j.1540-6520.2008.00275.x

Schulze, W. G., Lubatkin, M. H., \& Dino, R. N. (2003). Exploring the agency consequences of ownership dispersion among the directors of private family firms. Academy of Management Journal, 46(2), 179-194. http://dx.doi.org/10.2307/30040613

Schulze, W. G., Lubatkin, M. H., Dino, R. N., \& Buchholtz, A. K. (2001). Agency relationships in family firms: Theory and evidence. Organization Science, 12(2), 99-116. http://dx.doi.org/10.1287/orsc.12.2.99.10114

Schulze, W. S., \& Gedajlovic, E. R. (2010). Guest editors' introduction. Whither family business? Journal of Management Studies, 47, 191-204. http://dx.doi.org/10.1111/j.1467-6486.2009.00887.x

Sciascia, S., \& Mazzola, P. (2008). Family involvement in ownership and management: Exploring nonlinear effects on performance. Family Business Review, 21, 331-345. http://dx.doi.org/10.1177/08944865080210040105

Sirmon, D. G., \& Hitt, M. A. (2003). Managing resources: Linking unique resources, management, and wealth creation in family firms. Entrepreneurship Theory and Practice, 339-358. http://dx.doi.org/10.1111/1540-8520.t01-1-00013

Sraer, D., \& Thesmar, D. (2007). Performance and behavior of family firms: Evidence from the french stock market. Journal of the European Economic Association, 5, 709-751. http://dx.doi.org/10.1162/JEEA.2007.5.4.709

Stevens, C. E., Kidwell, R. E., \& Sprague, R. (2015). Bound by laws, or by values? Stewardship culture, national culture, and protection of minority owners in family firms. Corporate Governance: An International Review, 23(3), 203-215. http://dx.doi.org/10.1111/corg.12089

Tabellini, G. (2010). Culture and institutions: Economic development in the regions of Europe. Journal of the European Economic Association, 8(4), 677-716. http://dx.doi.org/10.1111/j.1542-4774.2010.tb00537.x

UniCredit-Capitalia. (2008). Decima indagine sulle imprese manifatturiere italiane. Rapporto Corporate, 1.

Van Ark, B., O’Mahony, M., \& Ypma, G. (2007). Productivity in the European Union: A comparative industry approach. EU KLEMS Productivity Report, $n .1$.

Van Essen, M., Heugens, P. P., Otten, J., \& Van Oosterhout, J. H. (2012). An institution-based view of executive compensation: A multilevel meta-analytic test. Journal of International Business Studies, 43(4), 396-423. http://dx.doi.org/10.1057/jibs.2012.6

Van Essen, M., Strike, V. M., Carney, M., \& Sapp, S. (2015). The resilient family firm: Stakeholder outcomes and institutional effects. Corporate Governance: An International Review, 23(3), 167-183. http://dx.doi.org/10.1111/corg.12087

Villalonga, B., \& Amit, R. (2006). How do family ownership, management and control affect firm value? Journal of Financial Economics, 80, 385-417. http://dx.doi.org/10.1016/j.jfineco.2004.12.005

Volpin, P. (2002). Governance with poor investor protection: Evidence from top executive turnover in Italy. Journal of Financial Economics, 64, 61-90. http://dx.doi.org/10.1016/S0304-405X(02)00071-5

Wagner, D., Block, J. H., Miller, D., Schwens, C., \& Xi, G. (2015). A meta-analysis of the financial performance of family firms: Another attempt. Journal of Family Business Strategy, 6, 3-13. http://dx.doi.org/10.1016/j.jfbs.2015.01.001

Wright, M., Chrisman, J. J., Chua, J. H., \& Steier, L. P. (2014). Family enterprise and context. Entrepreneurship Theory \& Practice, 1247-1260. http://dx.doi.org/10.1111/etap.12122

\section{Notes}

Note 1. The cleaning procedure was carried out as follows. Firms with negative values of value added were eliminated from the original archive. Moreover, in order to eliminate outliers, firms with a growth rate of value added and employee numbers below the first or above the ninety-ninth percentile of the distribution were also eliminated. Finally, in the sample used in estimating TFP, we ignore firms for which 7 years or more of data regarding employee numbers was not available.

Note 2. Voice and accountability is made up by the participation rate in public elections, the number of associations and social cooperatives, and cultural liveliness measured in terms of books published and purchased 
in bookshops; Government effectiveness measures the endowment of social and economic structures in Italian provinces and the administrative capability of provincial and regional governments in terms of health policies, waste management and environment; Regulatory quality regards the degree of openness of the economy, indicators of business environment, business density and the rate of firm mortality; Rule of law summarises data on crime against persons or property, magistrate productivity, trial durations, tax evasion and the shadow economy; Corruption summarises data on crimes committed against the Public Administration, the number of local administrations overruled by the federal authorities and the Golden-Picci Index, measuring the corruption level on the basis of "the difference between the amounts of physically existing public infrastructure and the amounts of money cumulatively allocated by government to create these public works. See Nifo and Vecchione (2014) for details of methodology adopted and all the elementary indexes used.

Note 3. Provinces (NUTS 3 level) are one of the three different levels of government (regions, provinces and municipalities) in Italy. According to the basic principles of the Nomenclature of Territorial Units for Statistics (NUTS) established by Eurostat and used by the European Commission, Italian provinces are NUTS 3 level.

Note 4 . We use the median because there are a few extreme values in the data set which render the average rather unrepresentative of the majority of the values.

Note 5. We use the median because there are a few extreme values in the data set which render the average rather unrepresentative of the majority of the values.

Note 6 . The correlation coefficients are very low among the firm-level predictors, which confirms that these variables capture distinct characteristics of firms (the correlation matrix is available on request). Naturally, this is not true in the case of the interaction variable between family management and age. For this reason, when this term is in the model, all independent variables are centred with respect to their grand means to guard against multicollinearity. In this case, the intercept represents the estimated value of the dependent variable when all independent variables are set equal to their grand means.

Note 7. The performance measures are Tobin's Q and ROA in Barontino and Caprio (2006) and Mauray (2006) and market value in Pindado et al (2008). Barontino and Caprio find that performance is significantly higher in founder-controlled corporations and corporations controlled by descendants who sit on the board as nonexecutive directors. When a descendant takes on the position of CEO, family-controlled companies are not statistically distinguishable from non-family firms.

Note 8. As for France and Spain, Sraer and Thesmar (2007) and Arosa et al (2010) focus on profitability and the role of family ownership by considering different generations of family-management and the effect on firm. Sraer and Thesmar (2007) find that French family managed firms, first or subsequent generations, outperform non-family firms. For Spanish firms the relationship between ownership concentration and performance is significant only in first generation family firms and is positive at a low level of ownership concentration and negative at a high level (Arosa et al., 2010).

Note 9. In the treatment effect model, the sample is divided into the treated (in our case, owner managed family firms) and the untreated (family firms run by outside managers) and the treatment (family management) is an endogenous process. The first step of the procedure is a probit model to estimate the probability of a firm's being managed by a family (the treatment equation). In the probit model, the regressors are the same controls used for the OLS as well as a dummy variable that is equal to one if, in the survey, the first stockholder claims to participate in an agreement to vote. We consider this variable as a proxy of family preference for control and, thus, a determinant of the family decision to keep hold of the management of the firm. We used the treatreg subroutine of the Stata package (see Cong \& Drukker 2000, for details). Miller et al (2007) and Amit et al (2015) used the same procedure to cope with endogeneity problems.

Note 10. The lambda parameter is $\lambda=\sigma \rho$ where $\rho$ is the correlation between the error term of equation (1), $\varepsilon$, and the error term of the probit model. If the correlation between the error terms $\rho$ is zero, then $\lambda=0$ and the problem is reduced to one estimable by OLS; if $\rho$ is positive (negative), $\lambda>0(\lambda<0)$ and OLS overestimates (underestimates) the treatment effect.

Note 11. The treatment effect model has also been applied to model 3, 4 and 5 of table 2 and the lambda coefficients are always not significant (results are available upon request).

Note 12. Brunello et al. (2003) show that the probability of a change of CEO after poor performance is reduced when the CEO owns some shares in the company or is a member of the owner family. Volpin (2002) provides evidence that the probability of a change in top management and the sensibility of this change to company results are significantly lower if the manager belongs to the family that controls the company. Lippi and 
Schivardi (2010) find that owners of family firms select managers almost only on the basis of private benefits: they retain the managers with whom they have developed a good relationship, regardless of ability and fire the others.

Note 13. Tabellini (2010) focuses on culture effect, measured by indicators of individual values and beliefs, such as trust and respect for others and confidence in individual self-determination, on regional development in 68 regions of eight European countries. Ketterer and Rodríguez-Pose (2016) and Rodríguez-Pose and Di Cataldo (2014) use both the Charron et al. (2014) indicators. The former in order to investigate how differences in institutional and geographical conditions have affected economic growth of European NUTS-2 regions of the EU-15. Considering the same regions, Rodríguez-Pose and Di Cataldo (2014) analyse how the quality of government shapes patenting. Lasagni, Nifo and Vecchione (2015) evaluate the impact of the Institutional Quality Index on TFP of Italian provinces.

Note 14. Manzocchi et al. (2014) focus on Italian provinces by using an indicator of social capital (newspaper per inhabitant) and of criminal incidence (the principal component that includes the number of beds in penal institutions, the number of convicts per 100 beds and the number of reported crimes) while Aiello et al (2014) consider Italian regions and an indicator of public administration efficiency built by Golden and Picci (2005).

Note 15. Manzocchi et al. (2014) implement a two-stage procedure in order to disentangle internal from external productivity drivers while Aiello et al. (2014) use a multilevel approach.

Note 16. In his classical study, Banfield (1958) devises the concept of "amoral familism" to describe families from southern Italy. According to Banfield, amoral families only apply the principles of good and evil inside the family while the same principles are irrelevant when dealing with non-family members.

Note 17. Details of the survey and the construction of the indicator can be found in Charron et al. (2014).

Note 18. The reference year for EQI is 2008 while our dependent variable refers to the 2004-2006 period. In using the EQI indicator to divide the Italian regions into the two groups, we assume that institutional variation remains relatively stable within countries in the period 2004-2008.

Note 19. The other possible answers are "Can't be too careful" and "Don't know".

Note 20. See Tabellini (2010) for more details.

Note 21. In the case of the trust indicator, the median is used to distinguish between low and high.

\section{Copyrights}

Copyright for this article is retained by the author(s), with first publication rights granted to the journal.

This is an open-access article distributed under the terms and conditions of the Creative Commons Attribution license (http://creativecommons.org/licenses/by/4.0/). 